\title{
Naphthoquinone Derivatives with Anti-Inflammatory Activity from Mangrove-Derived Endophytic Fungus Talaromyces sp. SK-S009
}

\author{
Hongju Liu ${ }^{1, *}$, Chong Yan ${ }^{1}$, Changqun $\mathrm{Li}^{1}{ }^{1}$, Tingting You ${ }^{1}$ and Zhigang She ${ }^{2, *} \mathbb{C}$ \\ 1 School of Pharmacy, Guangdong Medical University, 523808 Dongguan, China; jdsbj2000@163.com (C.Y.); \\ lcqstary@163.com (C.L.); youtt2013@163.com (T.Y.) \\ 2 School of Chemistry, Sun Yat-Sen University, 510275 Guangzhou, China \\ * Correspondence: liuhj8@mail2.sysu.edu.cn (H.L.); cesshzhg@mail.sysu.edu.cn (Z.S.); \\ Tel./Fax: +86-20-84113356 (Z.S.)
}

Received: 5 December 2019; Accepted: 22 January 2020; Published: 29 January 2020

\begin{abstract}
Twelve 1, 4-naphthoquinone derivatives, including two new (1 and 2) and 10 known (3-12), were obtained from endophytic fungus Talaromyces sp. SK-S009 isolated from the fruit of Kandelia obovata. All structures were identified through extensive analysis of the nuclear magnetic resonance (NMR), mass spectrometry (MS) and circular dichroism (CD), as well as by comparison with literature data. These compounds significantly inhibited the lipopolysaccharide (LPS)-induced nitric oxide (NO) production in the murine macrophage cell line (RAW 264.7 cells). The half maximal inhibitory concentration $\left(\mathrm{IC}_{50}\right)$ values, except for compound 2, were lower than that of indomethacin $(26.3 \mu \mathrm{M})$. Compound 9 inhibited the LPS-induced inducible nitric oxide synthase (iNOS) and cyclooxygenase-2 (COX-2) mRNA expressions in RAW 264.7 macrophages. Additionally, compound 9 reduced the mRNA levels of pro-inflammatory factors interleukin (IL)1 $\beta$, IL-6, and tumor necrosis factor (TNF)- $\alpha$. The results of this study demonstrated that these 1, 4-naphthoquinone derivatives can inhibit LPS-induced inflammation.
\end{abstract}

Keywords: 1,4-naphthoquinones; Talaromyces sp.; marine fungus; anti-inflammatory

\section{Introduction}

Inflammation is a normal immune process and one of the most important ways to protect the body from infection and tissue injury. However, prolonged or excessive inflammation can lead to a variety of diseases. Many diseases, such as arthritis, inflammatory bowel disease, neurodegenerative disorders, and septic shock syndrome, are related to inflammation. During the inflammatory process, the immune monocytes and macrophages can be stimulated and overexpress pro-inflammatory cytokines, including tumor necrosis factor (TNF)- $\alpha$, interleukin (IL)-1 $\beta$, and IL-6, as well as inflammatory factors such as nitric oxide (NO) and prostaglandin E2 (PGE2), produced by inducible nitric oxide synthase (iNOS) and cyclooxygenase-2 (COX-2), respectively [1]. Overproduction of these factors can lead to cell damage and inflammatory disease [2]. Therefore, inhibition of the production of these inflammatory mediators is an effective way to treat the inflammatory diseases [3].

Marine-derived endophytic fungi are important sources of bioactive compounds [4-7]. During our investigation of mangrove-derived endophytic fungus as sources of bioactive secondary metabolites, we isolated the endophytic fungus Talaromyces sp. SK-S009 from the fruit of Kandelia obovata. Organic extracts of rice solid culture showed significant anti-inflammatory activity. Chemical investigation of the extracts led to the isolation of twelve 1, 4-naphthoquinone derivatives (Figure 1). Here, we report the isolation, structure determination, and anti-inflammatory activities of 1, 4-naphthoquinone derivatives (1-12). 


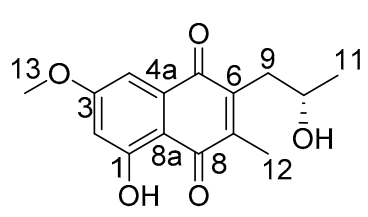

1<smiles>[R2]c1c(O)c2c(c3c1CC([R])[Ge]O3)C(=O)C(OC)=CC2=O</smiles>

$2 \mathrm{R}_{1}=\mathrm{CH}_{3} \quad \mathrm{R}_{2}=\mathrm{CH}_{2} \mathrm{OH}$

$3 \mathrm{R}_{1}=\mathrm{R}_{2}=\mathrm{CH}_{3}$

$4 \mathrm{R}_{1}=\mathrm{CH}_{2} \mathrm{OH} \quad \mathrm{R}_{2}=\mathrm{CH}_{3}$<smiles>COC1=CC(=O)c2c(O)c(C)c3cc(C)oc3c2C1=O</smiles>

5<smiles>COC1=CC(=O)c2c(O)c3c(c(O)c2C1=O)C=C(C)OC3</smiles>

6<smiles>COc1cc(O)c2c(c1)C(=O)C(CC(C)=O)=C(C)C2=O</smiles><smiles>[R]C(C)c1c(OC)cc2c(c1O)C(=O)C=C(OC)C2=O</smiles><smiles>COC1=CC(=O)c2c(O)c(C)c(CC(C)O)c(O)c2C1=O</smiles>

11<smiles>COC1=CC(=O)c2c(O)c(C)c(CC(C)=O)c(O)c2C1=O</smiles>

12

Figure 1. Structures of compounds 1-12.

\section{Results and Discussion}

\subsection{Metabolites Isolation}

The EtOAc extract of the fermentation was fractionated by repeated silica gel chromatography and Sephadex LH-20 column chromatography, as well as reversed phase high-performance liquid chromatography (RP-HPLC) to yield twelve 1, 4-naphthoquinone derivatives, including two new (1 and 2) and 10 known (3-12). The structures of the known compounds were identified as anhydrojavanicin (3) [8], 2,3-dihydro-5-hydroxy-4-hydroxymethyl-8-methoxy-2-methylnaphtho[1,2-b]furan-6,9-dione (4) [9], anhydrojavanicin (5) [10], anhydrofusarubin (6) [11], 2-acetonyl-3-methyl-5-hydroxy-7-methoxynaphthazarin (7) [12], 6-ethyl-2,7-dimethoxyjuglone (8) [13,14], 6-[1-(acetyloxy)ethyl]-5-hydroxy-2,7dimethoxy-1,4-naphthalenedione (9) [15], 5-hydroxy-6-(1-hydroxyethyl)-2,7-dimethoxy-1,4-naphtha lenedione (10) [16], solaniol (11) [17], and javanicin (12) [18], by comparison of their spectroscopic data with those reported in the literature.

\subsection{Structure Identification}

Talanaphthoquinone A (1) was isolated as a yellow, amorphous powder. The high-resolution electrospray ionization mass spectrometry (HRESIMS) spectrum (see Supplementary Materials Figure S1) displayed a molecular ion peak at m/z 275.09223 [M - H] $]^{-}$(calcd. for 275.09195), implying the molecular formula $\mathrm{C}_{15} \mathrm{H}_{15} \mathrm{O}_{5}$ (eight degrees of unsaturation). The ${ }^{1} \mathrm{H}$ NMR spectrum (Table 1) showed signals for one phenolic hydroxyl proton $\delta_{\mathrm{H}} 12.38(\mathrm{~s}, \mathrm{HO}-1)$, two meta-coupled aromatic protons $\left(\delta_{\mathrm{H}} 7.17(\mathrm{~d}, J=2.5 \mathrm{~Hz}, \mathrm{H}-4), \delta_{\mathrm{H}} 6.63(\mathrm{~d}, J=2.5 \mathrm{~Hz}, \mathrm{H}-2)\right)$, two methyl groups $\left(\delta_{\mathrm{H}} 2.21\left(\mathrm{~s}, \mathrm{H}_{3}-12\right)\right.$, $\left.\delta_{\mathrm{H}} 1.31\left(\mathrm{~d}, J=6.2 \mathrm{~Hz}, \mathrm{H}_{3}-11\right)\right)$, one methoxy $\left(\delta_{\mathrm{H}} 3.90\left(\mathrm{~s}, \mathrm{OCH}_{3}-13\right)\right)$, one oxygenated methine $\left(\delta_{\mathrm{H}} 4.04\right.$ $(\mathrm{dd}, J=11.9,6.0 \mathrm{~Hz}, \mathrm{OCH}-10))$, and one methylene $\left(\delta_{\mathrm{H}} 2.81\left(\mathrm{~s}, \mathrm{H}_{\mathrm{a}}-9\right), \delta_{\mathrm{H}} 2.80\left(\mathrm{~d}, J=1.7 \mathrm{~Hz}, \mathrm{H}_{\mathrm{b}}-9\right)\right)$. The ${ }^{13} \mathrm{C}$ NMR data (Table 1$)$ revealed two carbonyls $\left(\delta_{\mathrm{C}} 188.6,185.2\right)$, eight $\mathrm{sp}^{2}$-hybridized olefinic or aromatic carbons $\left(\delta_{\mathrm{C}} 165.9,164.2,145.7,144.6,133.7,109.7,107.8,106.1\right)$, three methyl groups $\left(\delta_{\mathrm{C}} 56.1\right.$, $12.9,24.4)$, one methylene $\left(\delta_{C} 36.8\right)$, and one methine $\left(\delta_{C} 67.9\right)$. The planar structure of 1 was mainly established by HMBC and COSY correlations (Figure 2). The HMBC correlations from one aromatic proton $\mathrm{H}-2\left(\delta_{\mathrm{H}} 6.63\right)$ to $\mathrm{sp}^{2}$ carbons $\mathrm{C}-3\left(\delta_{\mathrm{C}} 165.9\right)$ and $\mathrm{C}-8 \mathrm{a}\left(\delta_{\mathrm{C}} 109.7\right), \mathrm{H}-4\left(\delta_{\mathrm{H}} 7.17\right)$ to C-2 $\left(\delta_{\mathrm{C}} 106.1\right)$, C-3, C-5 $\left(\delta_{\mathrm{C}}\right.$ 185.2) and C-8a, led to the identification of the presence of a 1,3,4,5-tetrasubstituted benzene ring with a hydroxy, a methoxy, and two carbonyl groups attached at the C-1, C-3, C-4a, and C-8a, respectively. A methoxy group $\left(\delta_{\mathrm{H}} 3.90, \delta_{\mathrm{C}} 56.1\right)$ was located at C-3, supported by its HMBC 
correlations with C-3. The HMBC correlations of the hydroxyl proton at $\delta_{\mathrm{H}} 12.38$ with C-2 and C-8a confirmed an angular 1, 4-napthaquinone structure having an intra-molecularly hydrogen-bonded hydroxyl group at $\mathrm{C}-1$. The COSY correlations of $\mathrm{H}-10$ with $\mathrm{H}_{2}-9$ and $\mathrm{H}_{3}-11$, combined with the chemical shift of $\mathrm{C}-10\left(\delta_{\mathrm{C}} 67.9\right)$, showed the presence of one 2-hydroxypropyl group. The HMBC correlations from H-12 to C-6 $\left(\delta_{C} 144.6\right), C-7\left(\delta_{C} 145.7\right)$, and C-8 $\left(\delta_{C} 188.6\right), \mathrm{H}-9$ to C-5, C-6, and C-7 revealed the presence of another ring 1, 4-quinone, 2-hydroxypropyl group and $\mathrm{CH}_{3}-12$ were attached to the C-6 and C-7 of the napthaquinone ring, respectively. Mosher's method was tried to identify the absolute configuration of C-10 [19]. Unfortunately, alpha-methoxy-alpha-trifluoromethylphenylacetic acid (MTPA) esters were not detected. As a result, the absolute configuration of C-10 was determined by comparing experimental and calculated electronic circular dichroism (ECD) spectra [20]. As shown in Figure 3, the calculated ECD curves of $10 S$ was basically consistent with the CD curves obtained experimentally. Therefore, compound $\mathbf{1}$ was identified as shown in Figure 1.

Table 1. The ${ }^{1} \mathrm{H}$ and ${ }^{13} \mathrm{C}$ NMR data $\left(\mathrm{CDCl}_{3}, 500 / 125 \mathrm{MHz}\right)$ of compounds 1 and 2.

\begin{tabular}{|c|c|c|c|c|}
\hline \multirow{2}{*}{ Position } & \multicolumn{2}{|c|}{1} & \multicolumn{2}{|c|}{2} \\
\hline & $\delta_{\mathrm{C}}$ & $\delta_{\mathrm{H}}(J$ in $\mathrm{Hz})$ & $\delta_{\mathrm{C}}$ & $\delta_{\mathrm{H}}(J$ in $\mathrm{Hz})$ \\
\hline 1 & $164.2, \mathrm{C}$ & - & $190.1, \mathrm{C}$ & - \\
\hline 2 & $106.1, \mathrm{C}$ & $6.63, \mathrm{~d}(2.5)$ & $109.2, \mathrm{CH}$ & $6.07, \mathrm{~s}$ \\
\hline 3 & $165.9, \mathrm{C}$ & - & $161.4, \mathrm{C}$ & - \\
\hline 4 & $107.8, \mathrm{C}$ & $7.17, \mathrm{~d}(2.5)$ & $177.6, \mathrm{C}$ & - \\
\hline $4 a$ & 133.7, C & - & 109.1, C & - \\
\hline 5 & $185.2, \mathrm{C}$ & - & 155.0, C & - \\
\hline 6 & $144.6, \mathrm{C}$ & - & 139.0, C & - \\
\hline 7 & $145.7, \mathrm{C}$ & - & $134.2, \mathrm{C}$ & - \\
\hline 8 & $188.6, \mathrm{C}$ & - & 157.3, C & - \\
\hline $8 a$ & 109.7, C & - & $110.3, \mathrm{C}$ & - \\
\hline 9 & $36.8, \mathrm{CH}_{2}$ & $\begin{array}{c}2.81, \mathrm{~s} \\
2.80, \mathrm{~d}(1.7)\end{array}$ & $29.9, \mathrm{CH}_{2}$ & $\begin{array}{l}\text { 3.04, dd }(7.1,16.6) \\
\text { 3.20, dd }(9.4,17.0)\end{array}$ \\
\hline 10 & $67.9, \mathrm{CH}$ & 4.04, dd $(11.9,6.0)$ & $86.2, \mathrm{CH}$ & $5.15, \mathrm{~m}$ \\
\hline 11 & 24.4, $\mathrm{CH}_{3}$ & $1.31, \mathrm{~d}(6.2)$ & $64.5, \mathrm{CH}_{2}$ & $\begin{array}{l}3.76, \mathrm{~d}(8.6) \\
4.02, \mathrm{~d}(12.7)\end{array}$ \\
\hline 12 & $12.9, \mathrm{CH}_{3}$ & $2.21, \mathrm{~s}$ & $13.3, \mathrm{CH}_{3}$ & $2.25, \mathrm{~s}$ \\
\hline 13 & $56.1, \mathrm{CH}_{3}$ & $3.9, \mathrm{~s}$ & $56.7, \mathrm{CH}_{3}$ & $3.88, \mathrm{~s}$ \\
\hline $1-\mathrm{OH}$ & - & $12.38, \mathrm{~s}$ & - & $13.47, \mathrm{~s}$ \\
\hline
\end{tabular}

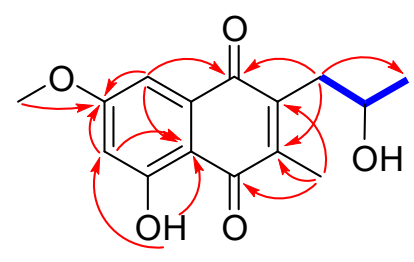

1

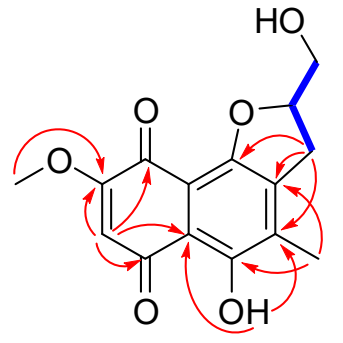

2

Figure 2. Key HMBC (red arrows) and COSY (blue bold lines) correlations of compounds 1 and 2.

Talanaphthoquinone B (2) was isolated as a red solid with $[\alpha]_{\mathrm{D}}^{25}:-16.8(c 0.1, \mathrm{MeOH})$. The HRESIMS spectrum displayed a negative ion peak at $\mathrm{m} / \mathrm{z} 307.08218\left[\mathrm{M}+\mathrm{H}_{2} \mathrm{O}-\mathrm{H}\right]^{-}$(calcd. for $\mathrm{C}_{15} \mathrm{H}_{15} \mathrm{O}_{7}$, 307.08178), corresponding to the molecular formula $\mathrm{C}_{15} \mathrm{H}_{14} \mathrm{O}_{6}$, implying nine degrees of unsaturation. The UV and IR spectra of 2 were similar to those of talanaphthoquinone A, indicating that they were structurally related. Aside from the characteristic naphthoquinone NMR signals due to two quinone carbonyls $\left(\delta_{C} 190.1,177.6\right)$ and eight aromatic/olefinic carbon resonances $\left(\delta_{C} 161.4,157.3\right.$, 155.0, 139.0, 134.2, 110.3, 109.3, 109.1), ${ }^{1} \mathrm{H}$ - and ${ }^{13} \mathrm{C}-\mathrm{NMR}$ spectrum (Table 1 ) showed the presence of 
signals due to two methyl groups $\left(\delta_{\mathrm{H}} 3.88, \delta_{\mathrm{C}} 56.7, \mathrm{OCH}_{3}-13 ; \delta_{\mathrm{H}} 2.25, \delta_{\mathrm{C}} 13.3, \mathrm{CH}_{3}-12\right)$, two methylene groups $\left(\delta_{\mathrm{H}} 3.20(\mathrm{dd}, J=17.0,9.3 \mathrm{~Hz}, 1 \mathrm{H}), \delta_{\mathrm{H}} 3.04(\mathrm{dd}, J=16.6,7.0 \mathrm{~Hz}, 1 \mathrm{H}), \delta_{\mathrm{C}} 29.9, \mathrm{CH}_{2}-9 ; \delta_{\mathrm{H}} 4.02\right.$ $\left.(\mathrm{d}, J=12.7 \mathrm{~Hz}, 1 \mathrm{H}), \delta_{\mathrm{H}} 3.76(\mathrm{~d}, J=8.7 \mathrm{~Hz}, 1 \mathrm{H}), \delta_{\mathrm{C}} 64.5, \mathrm{OCH}_{2}-11\right]$, an oxymethine group $\left(\delta_{\mathrm{H}} 5.15\right.$ $\left.(\mathrm{d}, J=3.7 \mathrm{~Hz}), \delta_{\mathrm{C}} 86.2, \mathrm{OCH}-10\right)$, one phenolic hydroxyl proton $\left(\delta_{\mathrm{H}} 13.47(\mathrm{~s}), \mathrm{HO}-8\right)$, and one aromatic proton $\left(\delta_{\mathrm{H}} 6.07(\mathrm{~s}), \mathrm{H}-2\right)$. The COSY correlations (Figure 2) of $\mathrm{H}-10$ with $\mathrm{H}_{2}-9$ and $\mathrm{H}_{2}-11$ showed the presence of an independent spin coupling system $-\mathrm{CH}_{2}-\mathrm{CH}-\mathrm{CH}_{2}$. The chemical shift of $\mathrm{C}-11$ indicated one hydroxyl group was located on C-11. HMBC spectrum (Figure 2) showed that $\mathrm{H}-2$ was correlated with C-1 $\left(\delta_{C} 190.1\right), C-3\left(\delta_{C} 161.4\right), C-4\left(\delta_{C} 177.6\right)$, and C-8a $\left(\delta_{C} 110.3\right)$, which could confirm that the only aromatic hydrogen was attached to the $C-2\left(\delta_{C} 109.2\right)$. A methoxyl group was linked to olefinic carbon C-3, supported by the HMBC correlation of $\mathrm{H}-13$ with C-3. The HMBC correlation of $\mathrm{H}-12$ with $\mathrm{C}-6\left(\delta_{\mathrm{C}} 139.0\right), \mathrm{C}-7\left(\delta_{\mathrm{C}} 134.2\right)$, and $\mathrm{C}-8\left(\delta_{\mathrm{C}} 157.3\right)$ indicated that the methyl group was connected to the C-7. The HMBC correlation of H-9 with C-5 $\left(\delta_{C} 155.0\right)$, C-6, C-7, indicated that C-9 was attached to the C-6. Phenolic hydroxyl group was located at C-8, as indicated by the HMBC correlation with C-7 and C-8. The naphthoquinone structure unit explained seven of the eight degrees of unsaturation in $\mathbf{2}$, implied by the molecular formula. The remaining one degree of unsaturation, together with downfield chemical shift of $C-10\left(\delta_{C} 86.2\right)$, indicated that $C-10$ was attached to $C-5$ to fuse a furan ring. In the light of the chemical shift of $C-11\left(\delta_{C} 64.5\right)$, the $C-11$ was a hydroxymethyl group. Therefore, the planar structure of compound 2 was elucidated as shown in Figure 1.

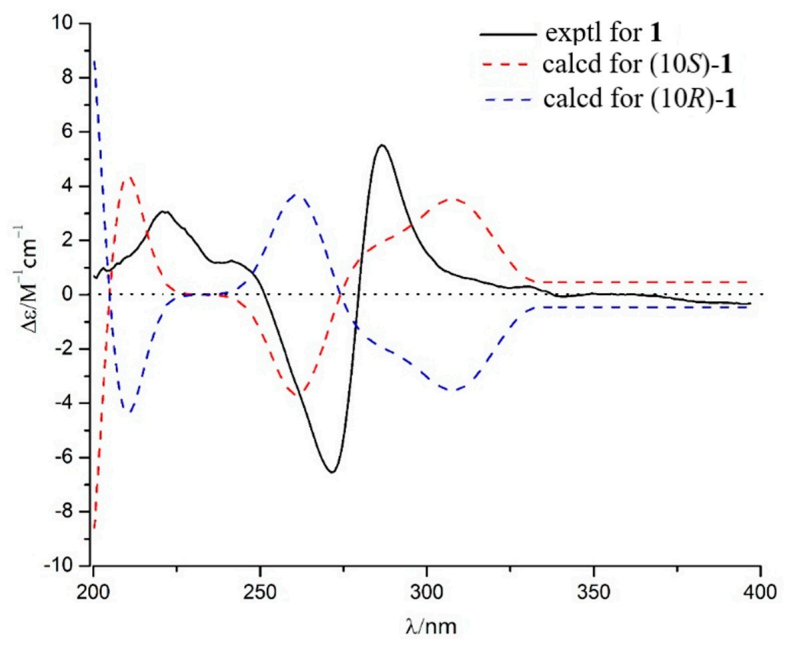

Figure 3. Calculated and experimental electronic circular dichroism (ECD) spectra of $\mathbf{1}$.

\subsection{Inhibitory Effects on NO Production}

All these isolates were tested for their inhibitory activities against lipopolysaccharide (LPS)-activated NO production in the murine macrophage cell line (RAW 264.7 cells). As shown in Table 2, all compounds could inhibit the production of NO with $\mathrm{IC}_{50}$ values ranging from 1.7 to $49.7 \mu \mathrm{M}$, while $\mathrm{IC}_{50}$ of indomethacin was $26.3 \mu \mathrm{M}$. It is suggested that the 1, 4-naphthoquinone is the active center of anti-inflammatory effect. Compound $\mathbf{2}$ has only one more hydroxyl group at position 11 than compound 3 in structure, but the inhibitory activity was apparently weaker, which indicates that the hydroxyl group at position 11 was not conducive to the anti-inflammatory activity. Their cytotoxic effects on RAW 264.7 cell lines was evaluated by the MTT assay. Six compounds (2-6 and 8) showed no cytotoxicity at a concentration of $50 \mu \mathrm{M}$. Six compounds $(\mathbf{1}, \mathbf{7}, \mathbf{9}, \mathbf{1 0}, 11$ and 12) revealed some cytotoxicity with the selective index $\left(\mathrm{SI}=\mathrm{CC}_{50} / \mathrm{IC}_{50}\right)$ values from 2.1 to 29.6 (Table 2$)$. The cytotoxicity data indicated that the third ring on the naphthoquinone can reduce the cytotoxicity to macrophage of mice. Compound 9 had lower cytotoxicity than 10, which revealed that the hydroxyacetylation on the side chain can also reduce the cytotoxicity. 
Table 2. Inhibitory activity of all compounds 1-12 against lipopolysaccharide (LPS)-induced NO production in the murine macrophage cell line (RAW 264.7 cells).

\begin{tabular}{cccc}
\hline Compounds & $\mathbf{I C}_{\mathbf{5 0}}(\boldsymbol{\mu M})$ & $\mathbf{C C}_{\mathbf{5 0}}(\boldsymbol{\mu M})^{\mathbf{a}}$ & $\mathbf{S I}^{\mathbf{b}}$ \\
\hline 1 & $3.9 \pm 0.5$ & $30.7 \pm 0.5$ & 7.9 \\
2 & $49.7 \pm 1.5$ & - & \\
3 & $16.0 \pm 0.2$ & - & \\
4 & $22.6 \pm 0.5$ & - & \\
5 & $11.2 \pm 0.3$ & - & 3.6 \\
6 & $5.2 \pm 0.1$ & $51.4 \pm 1.5$ & \\
7 & $14.4 \pm 0.6$ & - & 29.6 \\
8 & $7.7 \pm 0.3$ & $50.3 \pm 1.5$ & 2.1 \\
9 & $1.7 \pm 0.2$ & $15.8 \pm 0.4$ & 3.8 \\
10 & $7.5 \pm 0.2$ & $59.2 \pm 1.5$ & 8.6 \\
11 & $15.5 \pm 0.6$ & $48.4 \pm 1.3$ &
\end{tabular}

a Values are taken as the means \pm standard deviation, $n=3{ }^{\mathrm{b}} \mathrm{SI}$, selectivity index, calculated by $\mathrm{CC}_{50} / \mathrm{IC}_{50}{ }^{{ }^{\mathrm{c}} \mathrm{P}}$ ositive control; - No cytotoxicity was observed at a concentration of $50 \mu \mathrm{M}$.

\subsection{Inhibitory Effects on the Production of Inducible Nitric Oxide Synthase (iNOS), Cyclooxygenase-2} (COX-2), and Pro-Inflammatory Factors

Based on the results of inhibitory effects on NO production, compound 9 was found to be a significant inhibitor of $\mathrm{NO}$ with low cytotoxicity $(\mathrm{SI}=29.6)$. We have further investigated the effects of $\mathrm{CC}_{50} / \mathrm{IC}_{50}$ on mRNA expressions of inducible nitric oxide synthase (iNOS), cyclooxygenase-2 (COX-2), and the pro-inflammatory cytokines tumor necrosis factor (TNF)- $\alpha$, interleukin (IL)-1 $\beta$, and IL-6 in LPS-stimulated RAW 264.7 cells using real-time polymerase chain reaction (RT-PCR) analysis. As shown in Figure 4A-E, compound 9 apparently reduced the mRNA expressions of iNOS, COX-2, TNF- $\alpha$, IL- $1 \beta$, and IL-6 in a dose-dependent manner. Especially at the concentration of $2.0 \mu \mathrm{M}$, compound 9 inhibited the mRNA expressions of TNF- $\alpha$, IL- $1 \beta$, and IL- 6 by about $80 \%$ compared with the control groups.
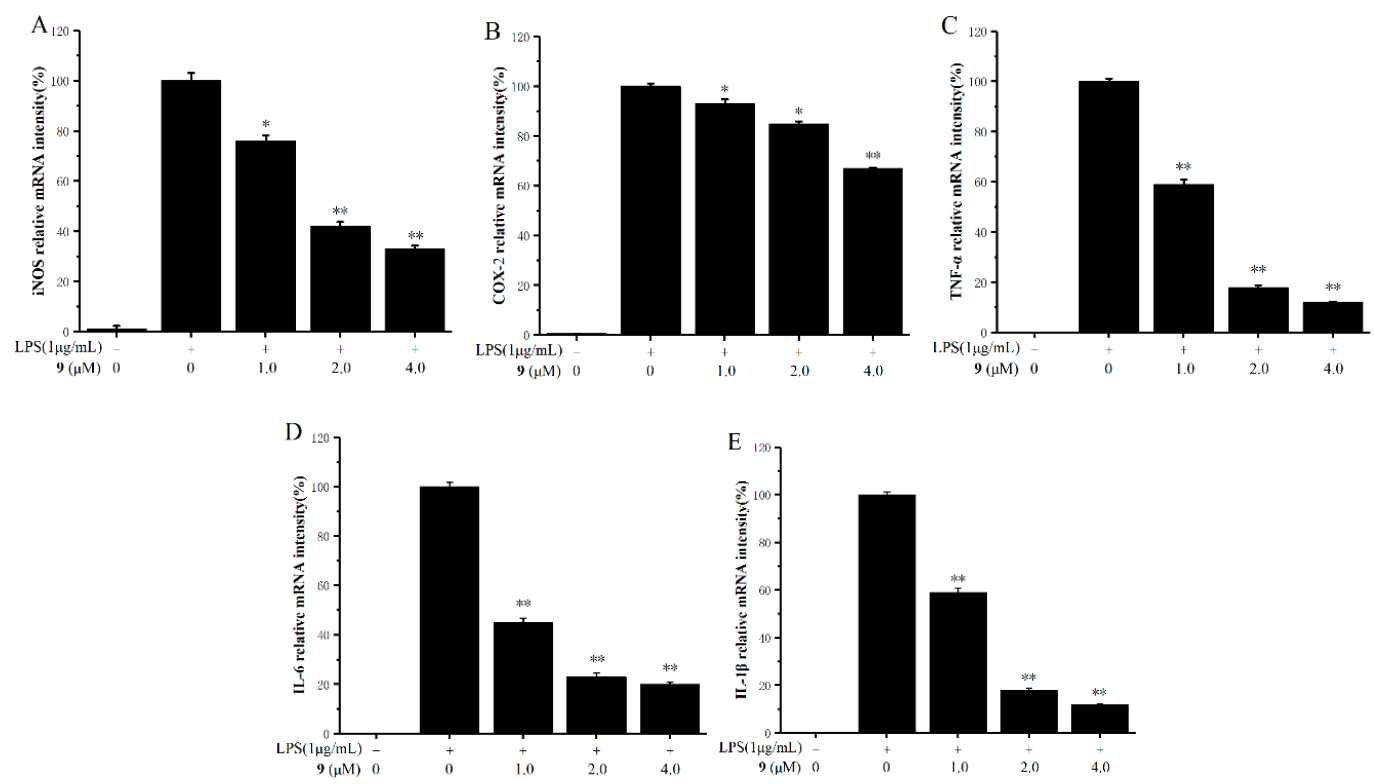

Figure 4. RAW 264.7 murine macrophage cells were pre-incubated for $12 \mathrm{~h}$, and then cells were pretreated with compound 9 at the indicated concentration for $1 \mathrm{~h}$ and incubated with LPS $(1 \mu \mathrm{g} / \mathrm{mL})$ for $12 \mathrm{~h}$ (real-time PCR). The effect of compound 9 on the mRNA expressions of inducible nitric oxide synthase (iNOS) (A), cyclooxygenase-2 (COX-2)(B), tumor necrosis factor (TNF)- $\alpha(\mathbf{C})$, interleukin (IL)-6 (D), and IL-1 $\beta$ (E) were detected by real-time PCR. The data represent the mean values \pm SD of three experiments, ${ }^{*} p<0.05,{ }^{* *} p<0.01$ compared to LPS-treated group. 


\section{Materials and Methods}

\subsection{General Experimental Procedures}

The 1D and 2D NMR data were recorded on Bruker Avance 400 and 500 spectrometer (Bruker BioSpin Corporation, Billerica, MA, USA), in which all chemical shifts $(\delta)$ are given in ppm with reference to tetramethylsilane (TMS), and coupling constants $(J)$ are given in Hz. EIMS data were measured on a dual stage quadrupole electron impact (DSQ EI)-mass spectrometer (Thermo, Shanghai, China) and the high-resolution electrospray ionization mass spectrometry (HRESIMS) were determined with a quadrupole time of flight (Q-TOF) high-resolution mass spectrometer (Waters Corporation, Synapt G2-Si, Milford, MA, USA). UV data were measured on a UV-240 spectrophotometer (Shimadzu, Beijing, China). IR data were recorded on a Nicolet 5DX-FTIR (Thermo Fisher Scientific, Inc., Hudson, NH), in KBr discs. Melting points were measured on an X-4 micromelting-point apparatus (Cany Precision Instruments Co., Ltd., Shanghai, China, uncorrected). Column chromatography (CC) was carried out on silica gel (200-300 mesh, Qingdao Marine Chemical Factory, Qingdao, China) and Sephadex LH-20 (Amersham Pharmacia, Piscataway, NJ, USA). GF-254 precoated silica gel plates (Qingdao Huang Hai Chemical Group Co., Qingdao, China) were used for thin layer chromatography. Semipreparative HPLC separation was performed on a Hitachi Primaide 1430 HPLC system (HITACHI, Tokyo, Japan) using a $\mathrm{C}_{18}$ column (Phenomenex, Torrance, CA, USA; $250 \times 10 \mathrm{~mm}, 5 \mu \mathrm{m}$ ) with the flow rate of $2.0 \mathrm{~mL} / \mathrm{min}$.

\subsection{Fungal Material}

The fungal strain used in this study was isolated from the fresh fruit of Kandelia obovata, which was collected from Shankou National Mangrove Nature Reserve in the South China Sea in September 2013. It was separated and identified by Senhua Chen using the standard protocol [21]. The sequence data obtained from the fungal strain were deposited at Gen Bank with accession no. MK368459. A BLAST search result revealed that the sequence was the most similar $(100 \%)$ to the sequence of Talaromyces amestolkiae (KT445914.1). A voucher strain was deposited in School of Chemistry, Sun Yat-Sen University, Guangzhou, China.

\subsection{Extraction and Isolation}

The fungus Talaromyces sp. SK-S009 was fermented on autoclaved rice solid-substrate medium in 80 500-mL Erlenmeyer flasks (each containing $50 \mathrm{~g}$ rice and $50 \mathrm{~mL}$ water with 3\%o of saline) for 28 days at $25{ }^{\circ} \mathrm{C}$. Following incubation, the mycelia and solid rice medium were extracted with EtOAc. The organic solvent was filtered and concentrated under reduced pressure to yield $40 \mathrm{~g}$ organic extract. The extract was subjected to silica gel CC using gradient elution with petroleum ether-EtOAc from 90:10 to 0:100 (v/v) to give 14 fractions (fractions1-14). Fraction 3 (600 $\mathrm{mg}$ ) was applied to Sephadex $\mathrm{LH}-20 \mathrm{CC}$ and eluted with $\mathrm{CHCl}_{3} / \mathrm{MeOH}$ (1:1) to obtain seven subfractions (fractions 3.1-3.7). Fraction $3.4(100 \mathrm{mg})$ was further purified by RP-HPLC $\left(70 \% \mathrm{MeOH}\right.$ in $\left.\mathrm{H}_{2} \mathrm{O}\right)$ to afford $5\left(12.1 \mathrm{mg}, t_{\mathrm{R}}=10.0 \mathrm{~min}\right)$ and $1\left(3.6 \mathrm{mg}, t_{\mathrm{R}}=15.6 \mathrm{~min}\right)$. Fraction $3.7(41 \mathrm{mg})$ was further purified by RP-HPLC $(65 \% \mathrm{MeOH}$ in $\left.\mathrm{H}_{2} \mathrm{O}\right)$ to afford $7\left(5.8 \mathrm{mg}, t_{\mathrm{R}}=22.0 \mathrm{~min}\right)$. Fraction $5(560 \mathrm{mg})$ was further purified by RP-HPLC $\left(70 \% \mathrm{MeOH}\right.$ in $\left.\mathrm{H}_{2} \mathrm{O}\right)$ to afford $12\left(10.8 \mathrm{mg}, t_{\mathrm{R}}=15.2 \mathrm{~min}\right), 3\left(15.4 \mathrm{mg}, t_{\mathrm{R}}=18.6 \mathrm{~min}\right)$, and $11(8.6 \mathrm{mg}$, $\left.t_{\mathrm{R}}=26.1 \mathrm{~min}\right)$. Fraction $7(503 \mathrm{mg})$ was further purified by silica gel CC using $80 \%$ EtOAc-light petroleum to afford seven subfractions (fractions 7.1-5.7). Fraction 7.3 (90 mg) was further purified by RP-HPLC (60\% MeOH in $\left.\mathrm{H}_{2} \mathrm{O}\right)$ to afford $4\left(20 \mathrm{mg}, t_{\mathrm{R}}=14.5 \mathrm{~min}\right)$. Fraction 8 (870 $\left.\mathrm{mg}\right)$ was applied to Sephadex $\mathrm{LH}-20 \mathrm{CC}$, eluted with $\mathrm{CHCl}_{3} / \mathrm{MeOH}(1: 1)$, to obtain 10 subfractions (fractions 8.1-8.10). Fraction 8.5 (25 mg) was further purified by Sephadex LH-20 CC, eluted with $\mathrm{CHCl}_{3} / \mathrm{MeOH}(1: 1)$, to afford $2(3.3 \mathrm{mg})$. Fraction $8.7(40 \mathrm{mg})$ was further purified by Sephadex LH-20 CC, eluted with $\mathrm{CHCl}_{3} / \mathrm{MeOH}(1: 1)$, to afford $6(13.3 \mathrm{mg})$. Fraction $9(680 \mathrm{mg})$ was applied to silica gel CC using $60 \%$ EtOAc-petroleum ether to afford seven subfractions (fractions 9.1-9.7). Fraction 10.3 was further 
purified by RP-HPLC ( $50 \% \mathrm{MeOH}$ in $\left.\mathrm{H}_{2} \mathrm{O}\right)$ to afford $8\left(7.3 \mathrm{mg}, t_{\mathrm{R}}=12.5 \mathrm{~min}\right), \mathbf{9}\left(9.1 \mathrm{mg}, t_{\mathrm{R}}=18.1 \mathrm{~min}\right)$, and $10\left(20 \mathrm{mg}, t_{\mathrm{R}}=20.4 \mathrm{~min}\right)$.

\subsubsection{Talanaphthoquinone A (1)}

Yellow powder $[\alpha]_{\mathrm{D}}^{25}:-17.0(c 0.1, \mathrm{MeOH}) ; \mathrm{IR}(\mathrm{KBr}) v_{\max }: 3375,1655,1633,1602,1576,1379,1302$, $1207,1167,1113,954,817,773 \mathrm{~cm}^{-1}$. UV (MeOH) $\lambda_{\max }(\log \varepsilon): 268(2.34), 219$ (3.63) nm. The ${ }^{1} \mathrm{H}$ and ${ }^{13} \mathrm{C}$ NMR spectroscopic data, see Table 1; HRESIMS (m/z $275.09223[\mathrm{M}-\mathrm{H}]^{-}$, calcd. for $\mathrm{C}_{15} \mathrm{H}_{15} \mathrm{O}_{5}$, 275.09195).

\subsubsection{Talanaphthoquinone B (2)}

Red solid $[\alpha]_{\mathrm{D}}^{25}$ : -16.8 (c $\left.0.1, \mathrm{MeOH}\right)$; m.p. $157.7-159.3^{\circ} \mathrm{C}$; IR (KBr) $v_{\max }: 3422,2981,1672,1636$, $1587,1473,1452,1252,1221,1165,1091,1031,962,930,886,863,816,790 \mathrm{~cm}^{-1}$. UV (MeOH) $\lambda_{\max }$ $\left(\log \varepsilon\right.$ ): 300 (2.45), 225 (3.89) nm. The ${ }^{1} \mathrm{H}$ and ${ }^{13} \mathrm{C}$ NMR spectroscopic data, see Table 1; HRESIMS $\left(\mathrm{m} / \mathrm{z} 307.08218\left[\mathrm{M}+\mathrm{H}_{2} \mathrm{O}-\mathrm{H}\right]^{-}\right.$, calcd. for $\left.\mathrm{C}_{15} \mathrm{H}_{15} \mathrm{O}_{7}, 307.08178\right)$.

\subsection{Measurement of NO Production and Cell Viability}

The nitrite/nitrate oxidized from NO was detected by the Griess reagent as previously reported with slight modifications [22,23]. The murine macrophage cell line (RAW 264.7 cells) were seeded in 96-well plates at a density of $1 \times 10^{5}$ cells/well and preincubated for $12 \mathrm{~h}$. The tested compounds were dissolved in dimethylsulfoxide (DMSO) and diluted with Dulbecco's Modified Eagle Medium (DMEM) medium to a final concentration (final DMSO concentration $<0.1 \%$ in all assays). Indomethacin was used as the positive control. Cells were stimulated with $1 \mu \mathrm{g} / \mathrm{mL}$ of lipopolysaccharide (LPS, Sigma, St. Louis, MO, USA) with or without tested compounds for $24 \mathrm{~h}$. Then culture supernatant was mixed with an equal volume of Griess reagent I and II (Beyotime, Shanghai, China), and measured at $540 \mathrm{~nm}$ using a microplate reader (Bio-Rad Laboratories, Inc., Kyoto, Japan). Cell viability was evaluated using MTT assay [24].

\subsection{Real-Time PCR}

RAW264.7 cells were placed in a 6-well plate at a density of $1 \times 10^{6}$ cells/well and incubated for $12 \mathrm{~h}$. Cultured cells were pretreated with compound $9(1,2,4 \mu \mathrm{M} / \mathrm{L})$ for $1 \mathrm{~h}$ and incubated with LPS $(1 \mu \mathrm{g} / \mathrm{mL})$ for $12 \mathrm{~h}$. RNA was extracted with Trizol Reagent (Takara Bio Inc., Otsu, Japan) according to the manufacturer's instructions, and cDNA was reverse transcribed from total RNA using a Superscript III system (Takara Bio Inc., Otsu, Japan). PCR amplification was carried out using PikoReal ${ }^{\mathrm{TM}}$ (Thermo Fisher Scientific, MA, US) and specific primers. The primer sequences (Wcgene Biotech, Shanghai, China) are shown in Table 3. The optimal conditions for PCR amplification of the cDNA were established by following the manufacturer's instructions. Relative gene expression was calculated using the comparative $\mathrm{Ct}$ method $\left(2^{-\Delta \Delta \mathrm{Ct}}\right)$ with glyceraldehyde-3-phosphate dehydrogenase (GAPDH) as an internal control. All experiments were performed in triplicate $(n=3)$.

Table 3. Primer sequences in this experiment.

\begin{tabular}{ccc}
\hline Primer & & Primer Sequence $\left(\mathbf{5}^{\prime}\right.$ to $\left.\mathbf{3}^{\prime}\right)$ \\
\hline \multirow{2}{*}{ iNOS } & Forward & GTCTTTGACGCTCGGAACTGTAG \\
& Reversed & TGAAGTCATGTTTGCCGTCACT \\
COX-2 & Forward & GATGACTGCCCAACTCCC \\
& Reversed & AACCCAGGTCCTCGCTTA \\
TNF- $\alpha$ & Forward & TGGCTGCTGAAAAGACACATGT \\
& Reversed & CCACCAGACGTTCTGCTGTCTAG \\
IL-1 $\beta$ & Forward & AGTTGACGGACCCCAAAAG \\
& Reversed & AGCTGGATGCTCTCATCAGG \\
IL-6 & Forward & TTCCATCCAGTTGCCTTCTTG \\
& Reversed & GGGAGTGGTATCCTCTGTGAAGTC \\
GADPH & Forward & TGTGTCCGTCGTGGATCTGA \\
& Reversed & TTGCTGTTGAAGTCGCAGGAG \\
\hline
\end{tabular}




\section{Conclusions}

The 1, 4-naphthoquinone derivatives were reported to show potential anti-inflammatory effect, including reducing 12-O-tetradecanoylphorbol-13-acetate (TPA)-induced acute inflammation in mouse ear [25], suppressing the production of TNF- $\alpha$ induced by LPS in mouse macrophages [25]. Suppressing TNF- $\alpha$ production in serum in vivo mouse model of LPS evoked acute inflammation [25], reducing cotton pellet- and carrageenin-induced paw edema in rat [26], and so on.

In this study, we isolated two new 1, 4-naphthoquinone derivatives, talanaphthoquinone A, B $(\mathbf{1}, \mathbf{2})$, along with 10 known analogues (3-12) from mangrove-derived endophytic fungus Talaromyces sp. SK-S009. All the compounds strongly inhibited LPS-induced NO production in RAW264.7 cell line in a dose-dependent manner. The NO production inhibition activities of all the compounds except for compound 2 were more potent than the positive control, indomethacin. Six compounds $(\mathbf{1}, \mathbf{7}, \mathbf{9}, \mathbf{1 0}, \mathbf{1 1}$, and $\mathbf{1 2})$ showed relatively less cytotoxicity to RAW264.7 cells with SI values varied from 2.1 to 29.6. A primary analysis of the structure-activity relationships was discussed. Furthermore, compound 9 reduced the mRNA levels of iNOS, COX-2, IL-1 $\beta$, IL-6, and TNF- $\alpha$. The results of this study demonstrated that these 1, 4-naphthoquinone derivatives can inhibit LPS-induced inflammation. This is the first report that compound 9 possesses anti-inflammatory activity.

Supplementary Materials: The following are available online, Figures S1-S12: HRESIMS spectrum, 1D- and 2D-NMR spectra of 1 and 2.

Author Contributions: Conceptualization and methodology, H.L. and Z.S.; experiment, H.L., C.Y., C.L., and T.Y.; data curation, H.L.; writing, original draft preparation, H.L. and C.Y.; writing, review and editing, H.L. and Z.S.; funding acquisition, H.L. and Z.S. All authors have read and agreed to the published version of the manuscript.

Funding: This research was funded by PhD researchers of Guangdong Medical University (grant number B2017028), the National Natural Science Foundation of China (grant number 81741162, 21877133, 21472251, 41906033), the Natural Science Foundation of Guangdong Province of China (grant number 2019A1515012084), Guangdong Special Fund for Marine Economic Development (grant number GDME-2018C004), the Key Project of Natural Science Foundation of Guangdong Province (grant number 2016A040403091), and the Special Promotion Program for Guangdong Provincial Ocean and Fishery Technology (grant number A201701C06).

Conflicts of Interest: The authors declare no conflict of interest.

\section{References}

1. Heller, R.A.; Schena, M.; Chai, A.; Shalon, D.; Bedilion, T.; Gilmore, J.; Woolley, D.E.; Davis, R.W. Discovery and analysis of inflammatory disease-related genes using cdna microarrays. Proc. Natl. Acad. Sci. USA 1997, 94, 2150-2155. [CrossRef] [PubMed]

2. Lee, T.S.; Tsai, H.L.; Chau, L.Y. Induction of heme oxygenase-1 expression in murine macrophages is essential for the anti-inflammatory effect of low dose 15-deoxy-delta 12, 14-prostaglandin J2. J. Biol. Chem. 2003, 278, 19325-19330. [CrossRef] [PubMed]

3. Wiesel, P.L.; Foster, C.; Pellacani, A.; Layne, M.D.; Hsieh, C.M.; Huggins, G.S.; Strauss, P.; Yet, S.F.; Perrella, M.A. Thioredoxin facilitates the induction of heme oxygenase- 1 in response to inflammatory mediators. J. Biol. Chem. 2000, 275, 24840-24846. [CrossRef] [PubMed]

4. Mayer, A.M.S.; Abimael, D.R.; Taglialatelascafati, O. Marine pharmacology in 2012-2013: Marine compounds with Antibacterial, antidiabetic, antifungal, anti-Inflammatory, antiprotozoal, antituberculosis, and antiviral activities; affecting the immune and nervous systems, and other miscellaneous mechanisms of action. Mar. Drugs 2017, 15, 2510-2573.

5. Cui, H.; Liu, Y.; Li, J.; Huang, X.; Yan, T.; Cao, W.; Liu, H.; Long, Y.; She, Z. Diaporindenes A-D: Four unusual 2, 3-dihydro-1H-indene analogues with anti-inflammatory activities from the mangrove endophytic fungus Diaporthe sp. SYSU-HQ3. J. Org. Chem. 2018, 83, 11804-11813. [CrossRef]

6. Liu, H.; Chen, S.; Liu, W.; Liu, Y.; Huang, X.; She, Z. Polyketides with immunosuppressive activities from mangrove endophytic fungus Penicillium sp. ZJ-SY2. Mar. Drugs 2016, 14, 217-223. [CrossRef]

7. Rosario, N.; Antonio, T. Bioactive compounds produced by strains of Penicillium and Talaromyces of marine origin. Mar. Drugs 2016, 14, 37-71. 
8. Zhang, L.; Zhang, W.; Liu, J.; Hu, J. C- F bond cleavage by intramolecular SN2 reaction of alkyl fluorides with O-and N-Nucleophiles. J. Org. Chem. 2009, 74, 2850-2853. [CrossRef]

9. MangasSánchez, J.J.; Busto, E.E.; Gotor-Fernández, V.V.; Gotor, V.V. Straightforward synthesis of enantiopure 2, 3-dihydrobenzofurans by a sequential stereoselective biotransformation and chemical intramolecular cyclization. Org. Lett. 2010, 12, 3498-3501. [CrossRef]

10. Kimura, Y.; Shimada, A.; Nakajima, H.; Hamasaki, T. Structures of naphthoquinones produced by the fungus, Fusarium sp., and their biological activity toward pollen germination. Agric. Biol. Chem. 1988, 52, 1253-1259. [CrossRef]

11. Baker, R.A.; Tatum, J.H.; Nemec, S. Antimicrobial activity of naphthoquinones from Fusaria. Mycopathologia 1990, 111, 9-15. [CrossRef] [PubMed]

12. Yang, Z.; Ding, J.; Ding, K.; Chen, D.; Shan, C.; Mei, G. Phomonaphthalenone A: A novel dihydronaphthalenone with anti-HIV activity from Phomopsis sp. HCCB04730. Phytochem. Lett. 2013, 6, 257-260. [CrossRef]

13. Medentsev, A.G.; Akimenko, V.K. Mechanism of phytotoxic action of naphthoquinone pigments of the fungus Fusarium decemcellulare. Phytochemistry 1992, 31, 77-79. [CrossRef]

14. Xia, X.; Liu, X.; Koo, D.C.; Sun, Z.; Shim, S. Chemical constituents of Fusarium sp. fungus associated with sea cucumbers. Chem. Nat. Com. 2014, 50, 1103-1105. [CrossRef]

15. Moore, R.E.; Singh, H.; Chang, C.W.J.; Scheuer, P.J. Polyhydroxy naphthoquinones: Preparation and hydrolysis of methoxyl derivatives. Tetrahedron 1967, 23, 3271-3305. [CrossRef]

16. Xu, Y.; Lu, C.; Zheng, Z. New polyketides isolated from Botryosphaeria australis strain ZJ12-1A. Helv. Chim. Acta 2011, 94, 897-902. [CrossRef]

17. Poch, G.K.; Gloer, J.B.; Shearer, C.A. New bioactive metabolites from a freshwater isolate of the fungus Kirschsteiniothelia sp. J. Nat. Prod. 1992, 55, 1093-1099. [CrossRef]

18. Sun, R.; Gao, Y.; Shen, K.; Xu, Y.; Wang, C.; Liu, H. Antimicrobial metabolites from the aquatic fungus Delitschia corticola. Phytochem. Lett. 2011, 4, 101-105. [CrossRef]

19. Chen, Y.; Liu, Z.; Liu, H.; Pan, Y.; Li, J.; Liu, L.; She, Z. Dichloroisocoumarins with potential anti-inflammatory activity from the mangrove endophytic fungus Ascomycota sp. CYSK-4. Mar. Drugs 2018, 16, 54. [CrossRef]

20. Zhao, D.; Shao, C.; Gan, L.; Wang, M.; Wang, C. Chromone derivatives from a sponge-serived strain of the fungus Corynespora cassiicola. J. Nat. Prod. 2015, 78, 286-293. [CrossRef]

21. Nielsen, K.F.; Smedsgaard, J. Fungal metabolite screening: Database of 474 mycotoxins and fungal metabolites for dereplication by standardised liquid chromatography-UV-mass spectrometry methodology. J. Chrom. A 2003, 1002, 111-136. [CrossRef]

22. Arsenault, G.P. Fungal metabolites-III: Quinones from fusarium solani D2 purple and structure of (+)-solaniol. Tetrahedron 1968, 24, 4745-4749. [CrossRef]

23. Liu, Y.; Yang, Q.; Xia, G. Polyketides with $\alpha$-glucosidase inhibitory activity from a mangrove endophytic fungus, Penicillium sp. HN29-3B1. J. Nat. Prod. 2015, 78, 1816-1822. [CrossRef] [PubMed]

24. Lee, M.H.; Lee, J.M.; Jun, S.H.; Lee, S.H.; Kim, N.W.; Lee, J.H.; Ko, N.Y.; Mun, S.H.; Kim, B.K.; Lim, B.O. The anti-inflammatory effects of Pyrolae herba extract through the inhibition of the expression of inducible nitric oxide synthase (iNOS) and NO production. J. Ethnopharmacol. 2007, 112, 49-54. [CrossRef] [PubMed]

25. Kobayashi, K.; Nishiumi, S.; Nishida, M.; Hirai, M.; Azuma, T.; Yoshida, H.; Mizushina, Y.; Yoshida, M. Effects of quinone derivatives, such as 1, 4-naphthoquinone, on DNA polymerase inhibition and anti-inflammatory action. Med. Chem. 2011, 7, 37-44. [CrossRef]

26. Fathy, H.M.; Aboushoer, M.I.; Baraka, A.; Abdel-Kader, M.S.; Omar, A.A. A New Naphthoquinone with Anti-inflammatory Activity from an egyptian collection of echiochilon fruticosum. Nat. Prod. Scien. 2009, 15, 22-26.

Sample Availability: Not available.

(C) 2020 by the authors. Licensee MDPI, Basel, Switzerland. This article is an open access article distributed under the terms and conditions of the Creative Commons Attribution (CC BY) license (http://creativecommons.org/licenses/by/4.0/). 